\title{
Association of the borer Spermophthorus apuleiae (Coleoptera; Curculionidae; Scolytinae) with the "pau-ferro" tree Caesalpinia ferrea (Leguminosae)
}

\author{
Lincoln Suesdek ${ }^{1,2,4}$ \& Flávio Cesar Thadeo Lima ${ }^{3}$ \\ ${ }^{1}$ Laboratório de Parasitologia, Instituto Butantan, \\ Av. Vital Brazil, 1500, CEP 05503-900, São Paulo, SP, Brazil \\ ${ }^{2}$ Instituto de Ciências Biomédicas, Biologia da Relação Patógeno-Hospedeiro, \\ Universidade de São Paulo - USP, CEP 05508-900, São Paulo, SP, Brazil \\ ${ }^{3}$ Museu de Zoologia da Universidade de São Paulo - USP, CP 42494, CEP 04299-970, \\ São Paulo, SP, Brazil, e-mail: fctlima@usp.br \\ ${ }^{4}$ Corresponding author: Lincoln Suesdek, e-mail: linrocha@butantan.gov.br
}

SUESDEK, L. \& LIMA, F.C.T. Association of the borer Spermophthorus apuleiae (Coleoptera; Curculionidae; Scolytinae) with the "pau-ferro" tree Caesalpinia ferrea (Leguminosae). Biota Neotrop. 11(2): http://www. biotaneotropica.org.br/v11n2/en/abstract?inventory+bn00211022011.

\begin{abstract}
The weevil subfamily Scolytinae includes beetles which may feed on the bark, trunk or roots of both live and dead trees and are sometimes considered forest and silvicultural pests. Less frequently, some species feed on seeds and may be cause economic losses when associated to plant cultivars. Spermophthorus apuleiae Costa-Lima is a Neotropical Scolytinae formerly recorded to be "associated" with seeds of Caesalpinia ferrea var. leiostachya Benth, a Brazilian tree popularly known in Portuguese as "pau-ferro". Hitherto, it was not clear whether these beetles actually feed on the seeds of that plant. In order to investigate the ability of S. apuleiae to feed on seeds of "pau-ferro", observations were done and colonies of these beetles were established. Both in the field and in captivity the beetles were not observed feeding on the seeds. Even when beetles were exposed to seeds as the only source of food they were incapable of boring or eating the seeds and died. Our data therefore suggest that S. apuleiae is a frugivorous species which peculiarly does not eat seeds of "pau-ferro".
\end{abstract}

Keywords: beetle, herbivory, seed, neotropical region.

SUESDEK, L. \& LIMA, F.C.T. Associação do besouro Spermophthorus apuleiae (Coleoptera; Curculionidae; Scolytinae) com a árvore "pau-ferro" Caesalpinia ferrea (Leguminosae). Biota Neotrop. 11(2): http://www. biotaneotropica.org.br/v11n2/pt/abstract?inventory+bn00211022011.

Resumo: Besouros da subfamília Scolytinae são por vezes considerados como pragas silviculturais e florestais devido ao hábito de alimentar-se de sementes, cascas, troncos e raízes de plantas. Algumas espécies se alimentam de sementes e podem causar danos econômicos quando associadas a cultivares vegetais. Spermophthorus apuleiae Costa-Lima é um escolitídeo neotropical originalmente registrado como "associado" a sementes de Caesalpinia ferrea var. leiostachya Benth, uma árvore brasileira popularmente conhecida como "pau-ferro". Até o momento, não estava claro se esses besouros realmente se alimentam das sementes dessa planta. Para investigar a habilidade de $S$. apuleiae alimentar-se de sementes de "pau-ferro", observações e colônias desses besouros foram estabelecidos. Tanto em campo como em cativeiro, os besouros não foram observados comendo sementes. Besouros expostos a sementes como a única fonte de alimento foram incapazes de perfurar ou comer as sementes e morreram. Os dados sugerem que $S$. apuleiae é uma espécie frugívora que peculiarmente não se alimenta de sementes de "pau-ferro".

Palavras-chave: besouro, herbivoria, semente, região neotropical. 


\section{Introduction}

Beetles of the weevil subfamily Scolytinae are usually known to feed on the bark, trunk or roots of live and dead trees and occasionally seeds. Although most species are decomposers of dead wood, some species are considered to be agricultural or tree orchards pests (Costa-Lima 1956, Rudinsky 1962, Paine et al. 1997, Flechtmann et al. 2001, Wood 2007). The seed borer species are potential pest species since they reduce the number of viable seeds (Costa-Lima 1956, Nakagawa et al. 2003).

Among the examples of seed feeding species, one may cite the coffee berry borer Hypothenemus hampei (Ferrari) that has its entire life cycle inside the coffee fruit Lima et al., 2003), and the date stone beetle, Coccotrypes dactyliperda Fabricius, which is a primary pest of green unripe fruits of date palms (Blumberg \& Kehat, 1982).

Spermophthorus apuleiae Costa-Lima is a Neotropical species which was formerly recorded by Costa-Lima (1956) to have the tree Caesalpinia ferrea var. leiostachya Ducke as a host. This is a Brazilian tree popularly known in Portuguese as "pau-ferro" which means literally "iron wood", regarding the extreme hardness of its wood. "Pau-ferro" trees have suffered a dramatic reduction of its original geographical distribution due to urbanization in Brazil (Lorenzi 1992). Therefore, knowledge on herbivorous insects which could affect the number of its viable seeds should be considered a central issue.

Costa-Lima (1956) briefly mentioned that S. apuleiae "occur in seeds" but did not state clearly whether they actually feed on the seeds of "pau-ferro". In addition, the general biology of this beetle is very poorly known and no information about it has been published since Costa-Lima's paper (1956). In order to investigate the behavior of this species and its capacity for damaging seeds of "pau-ferro", observations were made in the forest and foraging experiments were constructed to test this hypothesis.

\section{Material and Methods}

Fruits of C. ferrea var. leiostachya infested with S. apuleiae were collected in four localities in Brazil, three in São Paulo State (cities of São Paulo, Ribeirão Preto and Piracicaba, at their respective campi of São Paulo State University) and one in Espírito Santo State (city of Vitória, at the campus of Federal University). These localities are large suburban parks where "pau-ferro" occurs sub-spontaneously. Mature fresh infested fruits were found either on the trees or fallen on the soil and were recognised by the presence of $\sim 2 \mathrm{~mm}$ diameter holes bored by S. apuleiae (Figure 1). The beetles were removed from the fruits, identified to species and preserved in $70 \%$ ethanol. Voucher specimens from all localities were deposited in the entomological

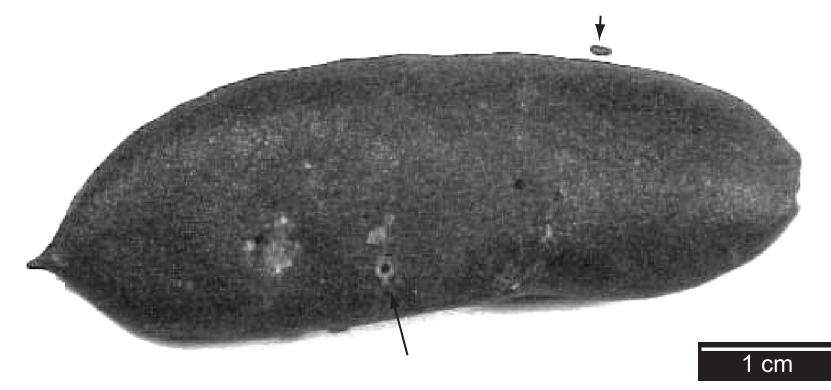

Figure 1. Mature fruit $C$. ferrea var. leiostachya bored by S. apuleiae. Long arrow indicates a hole made by the beetle. Short arrow indicates an adult of S. apuleiae. Scale bar $=1 \mathrm{~cm}$.

Figura 1. Fruto maduro de C. ferrea var. leiostachya perfurado por S. apuleiae. Seta longa indica perfuração feita pelo besouro. Seta curta indica um adulto de $S$. apuleiae. Barra de escala $=1 \mathrm{~cm}$. collection of Universidade Estadual Paulista (FEIS/UNESP), city of Ilha Solteira, State of São Paulo, Brazil.

Some infested fruits of "pau-ferro" from São Paulo city were brought to the laboratory where $S$. apuleiae colonies were maintained in captivity inside their original fruits for nine months. Three fruits were placed in each of ten isolated glass boxes. Water was sprayed onto the fruits once a week.

In order to determine the capacity of the beetles to eat the entire fruit including the seeds, in five boxes the beetles were kept in their original fruits and were subjected to food limitation, so that no new fruits or other food source were offered. As a positive control for the procedure of limitation of food, new non-infested fruits were added to the remaining five boxes, one fruit per box each two weeks. Eight weeks later, the new fruits were open to investigate the presence of beetles and the extent of herbivory. All fruits were kept inside the boxes till the end of the experiments. Nine months later, at the end of the experiments, all fruits were opened and the extent of damage was observed. The number of live beetles and larvae inside fruits were also counted.

To test the capacity of the individuals to infest seeds in the absence of other source of food, 20 adults (from freshly collected fruits) were transferred together to one new box containing seeds as the only source of food. As a positive control for the transfer procedure, another sample of twenty adults was transferred together to one new box containing three non-infested fruits, which were opened four weeks later.

\section{Results}

All localities sampled revealed fruits of C. ferrea var. leiostachya infested only with beetles determined as $S$. apuleiae. In the field, larvae and adults bored tunnels and fed predominantly on fruits mesocarp and rarely on exocarp, but not on the seeds.

Regarding the five boxes with new fruits, all of them had been infested at the end of the experiment. The fruits from the first 12 weeks were abandoned by the beetles after its mesocarp had been approximately $50 \%$ eaten. Fruits added after the $14^{\text {th }}$ week had its mesocarp eaten less than 50\% and resulted in about 5-14 living adults and 8-10 living larvae per fruit. The seeds remained intact and about 50-60 adults (from all fruits) were found dead on the bottom of each box.

Concerning the five boxes without new fruits, about 40 dead adults were observed in each box, most of them on the bottom of the boxes. Mesocarp of the fruits had been approximately $90 \%$ eaten, the seeds were not bored or eaten, and no living individuals were seen.

The sample of 20 adults exposed to seeds as the only source of food, died within six weeks without harming the seeds. The 20 adults transferred to fruits as a control managed to enter through the exocarp and four weeks later some larvae were detected inside the fruits.

\section{Discussion}

In general, S. apuleiae consumed about $50 \%$ or more of the fruit mesocarp and even more when food is restricted, and did not feed on seeds even when these were the only source of food. These results suggest that this insect is not a seed beetle, but rather a fruit feeding species. Beetles were not seen in tree pods, but even though we could not state with assurance if $S$. apuleieae does not feed on those tissues. Seeds of family Leguminosae are usually chemically protected against herbivory and this feature represents a barrier to most insects (Wink $\&$ Mohamed 2003). However there are some records of beetles which bore legume seeds (Johnson \& Lewis 1993), as far as we know, there are no Scolytinae among them. 
Most scolytins breed on wood and some species feed on fruits including the seeds, as for example H. hampe $i$ and some species of palm borers of the genera Coccotrypes and Xyleborus (Lima et al. 2003, Pizo et al. 2006, Blumberg \& Kehat 1982). In those examples, reproduction of the plant is jeopardized and, in the particular case of the palm Euterpe oleracea Martius, germination of its seeds may be $80 \%$ diminished by the presence of Xyleborus ferrugineus (Fabricius) as reported by Zorzenon \& Bergmann (1995). The frugivory reported here appear to be distinctive among Scolytinae because the beetle feed largely on fruit without damaging the seeds.

Although seeds were not injured, we still do not know whether seeds viability was indirectly affected by the activity of the beetles. According to Biruel et al. (2007), germination of seeds of $C$. ferrea is higher when seeds remain protected from daily weather changes inside the indehiscent fruits for at least eight months. If fruit tunnels made by S. apuleiae lead to a precocious exposure of seeds external conditions (rainfall, temperature, etc.), we could imagine that germination would be diminished. In another hypothesis, since scarification is not obligatory for breaking seed dormancy (Crepaldi et al. 1998), tunnels made by these beetles could allow a more rapid hydration of seeds and occasionally favor germination. Further studies will be necessary to test if any influence of $S$. apuleiae on seed germination actually exists. Although this is a preliminary study, present results and interpretations bring light to the little knowledge on both the tree C. ferrea var. leiostachya, a tree which has had a geographical distribution severely diminished in Brazil, and the beetle S. apuleiae.

\section{Acknowledgements}

We thank Dr. Carlos A. H. Flechtmann and Dr. Sergio A. Vanin for identification of several specimens. We also thank Mr. Luiz Leôncio Lorenzoni for collecting fruits in the city of Vitória, State of Espírito Santo.

\section{References}

BIRUEL, R.P., AGUIAR, I.B. \& PAULA, R.C. 2007. Germinação de sementes de pau-ferro submetidas a diferentes condições de armazenamento, escarificação química, temperatura e luz. Rev. Bras. de Sementes. 29(3):134-141.

BLUMBERG, D. \& KEHAT, M. 1982. Biological studies of the date stone beetle, Coccotrypes dactyliperda, Phytoparasitica. 10(2):73-78. http://dx.doi.org/10.1007/BF02981129
CREPALDI, I.C., SANTANA, J.R.F. \& LIMA, P.B. 1998. Quebra de dormência de sementes de pau-ferro (Caesalpinia ferrea Mart. ex Tul. - Leguminosae, Caesalpinioideae). Sitientibus. 18:19-29.

COSTA-LIMA, A.M. 1956. Insetos do Brasil: Coleópteros. Escola Nacional de Agronomia, Rio de Janeiro. $10^{\circ}$ Tomo. cap. 29, 4 pt.

FLECHTMANN, C.A.H., OTTATI, A.L.T. \& BERISFORD, C.W. 2001 Ambrosia and bark beetles (Scolytidae : Coleoptera) in pine and eucalypt stands in southern Brazil. Forest. Ecol. Manag. 142:183-191. http://dx.doi.org/10.1016/S0378-1127(00)00349-2

JOHNSON, C.D. \& LEWIS, G.P. 1993. New host records for Stator sordidus and S. limbatus (Coleoptera: Bruchidae) with comments on bruchid feeding guilds. Coleopt. Bull. 47:246-248.

LIMA, E.R., AMBROGI, B.G., COSTA, F.G. \& SARAIVA, R.M. 2003. Emprego de semioquímicos no manejo de pragas do café. In: Produção integrada de café (L. Zambolim, ed.). Universidade Federal de Viçosa, Viçosa, p. 47-66.

LORENZI, H. 1992. Árvores brasileiras: manual de identificação e cultivo de plantas arbóreas nativas do Brasil. Plantarum, Nova Odessa. v. 1.

NAKAGAWA, M., ITIOKA, T., MOMOSE, K., YUMOTO, T., KOMAI, F., MORIMOTO, K., JORDAL, B.H., KATO, M., KALIANG, H., HAMID, A.A., INOUE, T. \& NAKASHIZUKA, T. 2003. Resource use of insect seed predators during general flowering and seeding events in a Bornean dipterocarp rain forest. B. Entomol. Res. 93:455-466. http://dx.doi.org/10.1079/BER2003257

PAINE, T.D., RAFFA K.F. \& HARRINGTON, T.C. 1997. Interactions between scolytid bark beetles, their associated fungi and live host conifers. Ann. Rev. Entomol. 42:179-206. PMid:15012312. http://dx.doi.org/10.1146/annurev.ento.42.1.179

PIZO, M.A., ALLMEN, C.V. \& MORELLATO, L.P.C. 2006. Seed size variation in the palm Euterpe edulis and the effects of seed predators on germination and seedling survival. Acta Oecologica. 29(3):311-315. http://dx.doi.org/10.1016/j.actao.2005.11.011

RUDINSKY, J.A. 1962. Ecology of Scolytidae. Ann. Rev. Entomol. 7:327348. http://dx.doi.org/10.1146/annurev.en.07.010162.001551

WOOD, S.L. 2007. The Bark and Ambrosia Beetles of South America (Coleoptera: Scolytidae). Brigham Young University, Provo.

WINK, M. \& MOHAMED, G.I.A. 2003. Evolution of chemical defense traits in the Leguminosae: mapping of distribution patterns of secondary metabolites on a molecular phylogeny inferred from nucleotide sequences of the $r b c \mathrm{~L}$ gene. Biochem. System. Ecol. 31:897-917. http://dx.doi.org/10.1016/S0305-1978(03)00085-1

ZORZENON, F.J. \& BERGMANN, E.C. 1995. Ocorrência de Xyleborus ferrugineus (Fabricius, 1801) (Coleoptera: Scolytidae) em frutos e sementes de duas Espécies do gênero Euterpe. Rev. de Agricultura. 70:17-20. 